\title{
Exceptions to Copyright for Scientific and Educational Purposes
}

\author{
Roza Iosifovna Sitdikova ${ }^{1}$, Ekaterina Sergeevna Starostina ${ }^{1}$, \\ Elvina Rustemovna Kashapova ${ }^{1} \&$ Sergey Alexandrovich Baryshev ${ }^{2}$ \\ ${ }^{1}$ Department of Entrepreneurial and Energy Law at the Faculty of Law in K (V) FU, Kazan Federal University, \\ Russia \\ ${ }^{2}$ Department of civil law, Russian State University of Justice, Kazan branch, Russia \\ Correspondence: Roza Iosifovna Sitdikova, Department of Entrepreneurial and Energy Law at the Faculty of Law in \\ K (V) FU, Russia. E-mail: ms.rs575@gmail.com
}

Received: September 4, 2020

Accepted: October 20, 2020

Online Published: October 31, 2020

doi:10.5430/ijhe.v9n8p67

URL: https://doi.org/10.5430/ijhe.v9n8p67

\begin{abstract}
Copyright is a legal term that defines the rights that are given to the owners of the works in return for their intellectual and artistic works (according to the World Intellectual Property Organization). It establishes an appropriate balance between the benefits of the owner of the work and the common good. Apart from the exclusive rights of the owner of the work, this term also includes the regulations for public access to the works protected by the copyrights and the utility of these works for the common good. In this respect, with the copyright, the work owner is subject to some exceptions and limitations for the common good. Copyright restrictions are set depending on the development and needs of society. To ensure a fair balance of private, social, and public interests, copyright provides for the free use of works without the author's consent and without payment of remuneration. Such restrictions are necessary for the progressive development of society in all areas. Of course, one of the essential copyright restrictions that stimulate the development of new technologies and innovations is limitations for scientific and educational purposes.
\end{abstract}

Keywords: copyright, quotation, copyright exclusion, borrowing, work, free use of works

\section{Introduction}

Nowadays, Educational and scientific activities are an essential component of modern society. Moreover, as is evident, various intellectual activity types and the experience accumulated by previous scientists are widely used to implement these activities. From classical copyright law, such actions can be called borrowing, which should be carried out with the authors' permission of the works used, which is sometimes tricky (Bently, 2006). In order to surmount this obstacle, such a legal means as restricting the rights of authors of creative works are extensively utilized in modern intellectual property law. The essence of this restriction is that those cases are enshrined in the legislation when works can be used without an author's permission and without paying remuneration, but for the purposes strictly specified by law. Many such restrictions are especially connected precisely with educational and scientific activities (Alakurt, 2015; Rogers et al., 2009).

Therefore, the legislation of the Russian Federation, Part 1 of the article 1274 "Free use of a work for informational, scientific, educational or cultural purposes" of the Civil Code of the Russian Federation, established that the following actions (Civil Code of the Russian Federation. Part Four: Federal Law dated December 8, 2006) are allowed without the consent of the author or other copyright holder and payment of remuneration. However, with a mandatory indication of the author's name, whose work is used, and the borrowing source.

\section{Materials and Methods}

A quotation is carried out in the original and translated text for scientific, polemical, critical, informational, and educational purposes. However, a quotation is permitted only to reveal an author's creative intent and concerning legally published works. The legislator does not indicate a specific quotation volume but draws attention to the fact that the quotation's purpose should justify the quote volume. As pointed out by the Intellectual Property Rights Court in the 
Decree dated February 2, 2016, No. S01-1236 / 2015 in case No. A40-41816 / 2015, "the quote looks like one or more extracts from the works of other authors, based on which the quoting author illustrates his/her theses, confirms his/her assumptions, criticizes or disputes the arguments with which he/she does not agree; this determines the difference between quoting and copying" (Resolution of the Intellectual Property Rights Court dated 02.02.2016 in case No. S01-1236 / 2015).

According to the position of the Supreme Court of the Russian Federation outlined in the Decree dated December 5, 2003, in case No. 78-G03-77 (Decision of the Supreme Court of the Russian Federation dated December 5, 2003, in case No. 78-G03-77) quotation is made to illustrate, confirm or refute the author's statements. Moreover, quotation refers to the inclusion of one or more excerpts from one author's work in another author's work.

The next permitted action is the possibility of using legally published works and excerpts from them as illustrations in publications, radio and television broadcasts, and sound and video recordings of an educational nature in an amount justified by the intended purpose.

Moreover, these actions should be carried out in compliance with the author's rights of the works used, namely with the obligatory indication of the author's name and the source of the quotation.

Following the amendments introduced by the Federal Law dated 12.03.2014 No. 35-FZ (Federal Law "On Amendments to Parts One, Two and Four of the Civil Code of the Russian Federation and Separate Legislative Acts of the Russian Federation" dated 03.03.2014), recording on electronic media is allowed, including recording in computer memory, and bringing abstracts of theses to the public.

An exciting addition was introduced according to the amendments made by the Federal Laws dated March 12, 2014 No. 35-FZ, November 28, 2015, No. 358-FZ: they additionally permitted the public performance of legally published works by their presentation in live performance, which was carried out without the purpose of making a profit in educational organizations, medical organizations, social service organizations and institutions of the penitentiary system by the workers (employees) of these organizations and institutions and by persons respectively served by these organizations or held in these institutions.

Similar restrictions are contained in the legislation of other foreign countries.

\section{Results and Discussion}

French copyright contains a fairly extensive list of grounds for "free use of works", also referred to as "exceptions to copyright". At the same time, the two above terms are directly absent in the French Intellectual Property Code of 1992 (hereinafter CPI) (Loi ${ }^{\circ}$ 92-597 du 1 juillet 1992 relative au Code de la propriété intellectuelle (partie législative)) and are developed by French copyright science and judicial practice.

Several criteria determine the legality of the free use of works. These criteria can be classified into two groups. The first includes general conditions (criteria) that apply to all cases of free use. The second group includes criteria that serve as the basis for the application of certain exceptions to copyright.

The first group of criteria includes the admissibility criterion for the free use of a work, which is at the same time a fundamental principle of French copyright. In accordance with this principle, the author's personal non-property (moral) rights are inherent and inalienable from an author's personality. In connection with it, any restrictions on the rights of author may affect only his/her property rights, including the rights to reproduce and represent. Therefore, even the use of works for generally useful, cultural, and scientific purposes cannot violate the author's moral rights, which is manifested, in particular, in need to indicate the name of the author when using his/her work for educational purposes.

The second most important criterion is the possibility of applying copyright restriction rules concerning only legally published works. Work is included in the commercial turnover and can be used only from the moment of its publication (Helen Raison, 2020). Accordingly, no copyright restrictions may apply to works that have not been published directly by the author or with his/her explicit consent. Thus, if a work was not made public, including after its author's death, then the prohibition on its use, and, consequently, on the application of restrictions on scientific and pedagogical activity against him, continues to apply to him/her. This provision leads to a formal prohibition on quoting those works that have not been published.

The third most important condition is that the restriction will be legal only in that case if it was provided for by Art. L122-5 CPI. The list of grounds for limiting copyright contained in this article is exhaustive and not subject to extensive interpretation. On the other hand, this provision means that in case of any doubt caused by the lack of 
detailed legislative regulation, such as, for example, in the case of the text size of the work used for quotation, the person using this restriction is obliged to interpret these standards as strictly and formally as possible.

Another essential condition that applies to all cases of copyright restriction, without exception, is the requirement to avoid any actions that may interfere with the regular use of the work. The universality of this provision is manifested in the fact that even if the interested person's actions formally fall under the grounds of copyright restriction, these actions should still take into account the interests of persons legally using the work. For example, an exception regarding the ability to use excerpts of works for educational purposes by copying should not violate the interests of persons who have the right to reproduce it by reprography.

The last general condition is the need to refrain from actions that could cause unjustified damage to the author's interests when using a work within the limits of copyright restrictions. This condition underlies the reasonableness of the application of various restrictions. For example, it applies to the reproductions and presentations performed by individuals regarding architectural and sculptural works located in public places and without the purpose of their commercial use. Suppose an image (photograph) of such a sculptural work begins to be used for commercial purposes, for example. In that case, if an individual provides it for use by a legal entity, there will obviously be an action that incurs losses to the author of the work.

According to French copyright law, the grounds for which certain exceptions to copyright arise are quite diverse. These exceptions can be systematized for various reasons. An analysis of CPI articles, taking into account the rules governing the granting of permission for reprographic copying, allows us to identify several main groups of exceptions to copyright.

A significant place among them is occupied by exceptions established for scientific and educational purposes. These exceptions are designed to ensure freedom of scientific activity, cultural exchange, as well as the effectiveness of pedagogical and educational activities. At the same time, these exceptions should not violate the moral and property rights of the author.

It should be noted that French law and practice are quite strictly approaching the problem of observing authors' rights when using their work for scientific and educational purposes. This exception's general regulation is contained in paragraphs "a" and "f", item 1, article L122-5 of the CPI. According to paragraph "a", item 1, article L122-5 of the CPI, an exception to copyright is the possibility to make short quotes, the use of which is justified by the critical, polemic, educational, scientific or informational nature of the work in which they are included. The quote should not reveal the content of the entire work. The purpose of the quotation should determine its volume. In turn, a text that is a collection of individual short quotes from work cannot be considered as falling under the copyright restrictions and can be regarded as counterfeit use (Emmanuel Pierrat, 2020).

Paragraph "e", item 1, article L122-5 of the CPI defines the order in which works are used for educational purposes. It should be noted that French copyright quite strictly regulates this issue.

Firstly, use can be carried out both in the form of reproduction and presentation, including in digital form.

Secondly, the use should be in the form of excerpts of works according to the illustrative purposes in the process of teaching and research activities, with the purpose to be included in the development and dissemination of examination and competitive assignments based on the results of training. This exception does not apply to cases of use of a work in gaming and entertainment. Works created for educational purposes and musical scores are excluded from the number of works that fall under such use.

Thirdly, such use is possible only in an audience consisting mainly of pupils, students, teachers, researchers, who are directly involved in teaching, learning or scientific activity requiring such presentation or distribution.

Fourth, such use cannot include the distribution of works among third parties and the public, and also cannot pursue commercial goals and must be accompanied by financial compensation in the form of a fixed amount, taking into account the provisions of Article L. 122-10.

UK copyright also contains a large number of grounds for "free use of works". The Copyright, Designs and Patents Act of 1988 (hereinafter referred to as the CDPA 1988) in its Section 3 "Actions Permitted in Respect of Works Protected by Copyright" establishes all possible cases of free use of copyright objects in which exclusive right does not require author's or copyright holder's consent (Copyright, Designs and Patents Act 1988).

There are several legally established criteria for the permissibility of free use of works for each case, while the guiding principle for some purposes of use is the concept of "fair dealing". CDPA 1988 does not enshrine the 
definition of "good faith"; therefore, based on prevailing jurisprudence, the assessment of "good faith" is made in each individual case (Sitdikova \& Starostina, 2017).

So, for example, following article 29 of the CDPA 1988, the concept of "fair dealing" is applied to the free use of works for research and private education. Conducting research and private training are not identical activities. Conducting scientific research is a work that is carried out by an individual, either in the interests of the organization or to promote science as a whole. And private education is carried out for the personal benefit of the person who carries out such actions. Therefore, this activity can be directed solely to improve their own qualifications as a specialist in a particular field.

The critical point is that such actions will be covered by the rules on the permitted free use of works only if they are carried out for non-commercial purposes.

This rule assumes, first of all, copying material for scientific research. It is assumed that a large volume of a book or an entire article can be copied if such a quantity is necessary for research or private study. This user right is primarily aimed at promoting research and private education. Copyright should not become a financial and practical factor hampering research and private learning. It is necessary to strike a balance between the interests of copyright owners and society in the proper functioning of the copyright system and the interests of society for development through scientific research and private research of its members" (Torremans, 2016).

In addition, article 29 of the CDPA 1988 states that in order for the use to be recognized as fair, it is necessary to indicate the source of the material used and refer to its author.

For the purpose of research, CDPA 1988 provides yet another Section 29A, "Copies for Text and Data Analysis intended for Non-profit Research". In accordance with this rule, it is allowed to create a copy of a work by a person who has legal access to the work, provided that the copy is made so that the person who has legal access to the work can carry out a computational analysis of everything that is recorded in work for the sole purpose of research for non-profit purposes and provided that the copy is accompanied by information about the source and author of the work used.

It is interesting that the definition of computer analysis of text and data is not enshrined in the CDPA 1988, but the website of the Intellectual Property Office of the United Kingdom indicates that this should be understood as the use of automated analytical methods to analyze text and data for patterns, trends and other useful information (https://www.gov.uk).

This norm is a relatively recent innovation and was part of the comprehensive reform of the CDPA 1988 in 2014, which aimed to provide a legal basis for the use of new technologies in line with the digital age.

Articles 32-36A of the CDPA 1988 are devoted to the free use of works for educational purposes: article 32 is for "illustration for learning", article 33 is devoted to "anthologies for educational use", article 34 concerns "performance, reproduction or demonstration of work in the course of an educational institution", article 35 covers "recording of educational programs institutions", article 36 is for "copying and use of excerpts of works by educational institutions", article 36A concerns to "providing copies by educational institutions". Thus, these are six cases of free use of works provided for and regulated by law for educational purposes only.

\section{Summary}

All of the above norms are quite voluminous as to their content and describe the procedure for such use in detail. So, for example, article 36 gives educational institutions the right to copy excerpts from works, provided that the copy is made for educational and non-commercial purposes and citations accompany the copy to publications of the author of the work. In addition, this copy of the extract can be transferred by the educational institution or on its behalf to its students or employees for the purpose of training for non-commercial purposes.

An important norm for ensuring citizens' interests in the digital environment is the provision of digital copies of these data through a secure electronic network accessible only to students and employees of the educational institution.

This article also establishes a quantitative criterion: no more than $5 \%$ of the entire work can be copied by or on behalf of an educational institution in 12 months. 


\section{Conclusion}

Thus, we can conclude that the cases of copyright restrictions for scientific and educational purposes in the countries' laws in question are quite different. This is largely due to the fact that at the international level, there is no uniform approach in national laws to the regulation of civil law limitations of exclusive copyrights. Moreover, the general rule on the free use of works in national legislation for scientific and educational purposes is common: restrictions on exclusive rights are established in certain special cases, provided that such restrictions do not contradict the normal use of works, do not unreasonably prejudice the legitimate interests of authors and copyright holders.

\section{Acknowledgements}

The work is performed according to the Russian Government Program of Competitive Growth of Kazan Federal University.

\section{References}

Alakurt, T. (2015). Fair Use Rights in the Digital World: A Phenomenological Study of Instructional Technology Specialists. International Journal of Higher Education, 4(4). https://doi.org/10.5430/ijhe.v4n4p25

Bently, L. (2006). Parody and Copyright in the Common Law World in Copyright and Freedom of Expression, Proceedings of the ALAI conference Barcelona, Huygens, pp. 355-389.

Civil Code of the Russian Federation. Part Four: Federal Law dated December 8, 2006 No. 230-FZ // Collected Legislation of the Russian Federation. - 2006. - No. 52 (Part 1). - Art. 5496.

Copyright, Designs and Patents Act. (1988). Retrieved from http://www.legislation.gov.uk/ukpga/1988/48/part/I/chapter/III

Decision of the Supreme Court of the Russian Federation dated December 5, 2003 in case No. 78-G03-77 // access from the "Consultant Plus" law reference system

Emmanuel Pierrat. Les limites du droit de quotation. Livre Hebdo // Retrieved from https://www.livreshebdo.fr/article/les-limites-du-droit-de-quotation

Exceptions to copyright. Retrieved from https://www.gov.uk/guidance/exceptions-to-copyright

Federal Law "On Amendments to Parts One, Two and Four of the Civil Code of the Russian Federation and Separate Legislative Acts of the Russian Federation" dated 03.03.2014 No. 35-FZ // Collected Legislation of the Russian Federation, 03.17.2014, No. 11, Art. 1100.

Helen Raison. La contractualisation du droit moral de l'auteur/ these pour obtenir le grade de docteur de l'Universite d'Avignon et des Pays de Vaucluse. Discipline: droit// Retrieved from https://www.theses.fr/2014AVIG2041/document/

Loi $\mathrm{n}^{\circ}$ 92-597 du 1 juillet 1992 relative au Code de la propriété intellectuelle (partie législative) // Journal officiel de la Republique française du 3 juillet 1992.

Resolution of the Intellectual Property Rights Court dated 02.02.2016 in case No. S01-1236 / 2015, and in case No. A40-41816 / 2015 // Access from the "Consultant Plus" law reference system.

Rogers, M., Tomalin, J., \& Corrigan, R. (2009). The Economic Impact of Consumer Copyright Exceptions: A literature review Oxford. Harris Manchester College and London; Consumer Focus.

Sitdikova, R., \& Starostina, E. (2017). The development of the parody exception to the copyright in the United Kingdom. National Academy of Managerial Staff of Culture and Arts Herald, 2, 72-76.

Torremans, P. (2016). Intellectual property law. Oxford University Press, 290. https://doi.org/10.1093/he/9780198734772.003.0001

\section{Copyrights}

Copyright for this article is retained by the author(s), with first publication rights granted to the journal.

This is an open-access article distributed under the terms and conditions of the Creative Commons Attribution license (http://creativecommons.org/licenses/by/4.0/). 